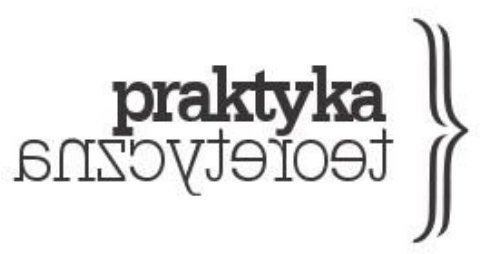

ISSN 2081-8130

DOI: $10.14746 /$ prt.2018.3.6 www.praktykateoretyczna.pl

\title{
RETHINKING THE FAILURE OF THE FRENCH FOURIERIST COLONY IN DALLAS
}

\author{
MICHEL CORDILLOT
}

\begin{abstract}
It has generally been accepted that the attempt of the French Fourierists to set up a colony in Texas on the eve of the Civil War was a complete failure. But was that really the case? A reexamination of the colony's legacy will show that it was more complex and far-reaching than previously thought.
\end{abstract}

Key words: Fourierism, La Réunion, phalanstery, Texas, the 19th century, Victor Considerant 
Why does the failed attempt of the French Fourierists to set up a socialist colony in Texas on the eve of the Civil War deserve reexamination? ${ }^{1}$ After all, that colony broke down quickly and might at first sight seem to have been a far from remarkable case on the long list of failed utopian experiments in the history of the United States of America. The point is, however, that when considering its legacy and the consequences that ensued in a broader perspective, the story of Reunion can hardly be written off as a complete disaster. Besides, a reexamination of this largely forgotten episode may also prove helpful in rethinking the problems that appear when yearnings for a brighter future collide with harsh reality.

Let us first return to the context in which a group of European followers of the French social philosopher Charles Fourier (1772-1837) decided to cross the Atlantic ocean in 1855 to settle in the middle of nowhere in the Texan prairie to found Reunion under the guidance of his main disciple, Victor Considerant. ${ }^{2}$ This attempt took place a few years after LouisNapoléon Bonaparte's violent seizure of power in France on December 2, 1851. Considerant himself had been forced into exile in Belgium after the riotous demonstration of June 13, 1849, together with other luminaries of the movement. Responding to the insistent invitation of his American friend Arthur Brisbane, he decided in November 1852 to visit the United States, a country where Fourierism had achieved a marked influence in the 1840 s - leading to about 40 recorded attempts, most of them short-lived, to set up a phalanstery (Guarneri 1991).

Back in Europe, many of those who hoped to create an ideal future for themselves saw the USA as a culturally diverse and tolerant young nation. Its social structures were far less rigid than those of the Old World due to the absence of a feudal past, and its scarcely populated hinterland would provide an ideal setting for all sorts of social experiments. Fourier himself had insisted on what he called "realization", or creating an environment where his theories about the role of passions in achieving harmony might be tested. His plans - and later those of his followers - to build a new society were based on transforming society progressively rather than creating new social structures ex nibilo (as the followers of Cabet tried to do, also in the USA, after 1848) (Prudhommeaux 1907; Fourn 2014). Far from aiming to destroy the then nascent capitalism, the Fourierist project was conceived as both a progressive utopia anticipating future developments accompanying the industrial revolution and a remedy for the evils that were threatening to cause a new series of bloody social outbursts. According to them, the aim was to offer an alternative path towards a peaceful social evolution from which all classes of society would have something to gain.

Initially reluctant to voyage to the USA, upon arrival Considerant was at once spellbound by this new, overactive country and by the fascinating western landscapes he discovered during

\footnotetext{
${ }^{1}$ I wish to thank Anna Cartier for her editorial work on this paper.

2 About Considerant, see: Beecher 2001. For details on the broader context, see: Cordillot 2013.
} 
his tour on horseback with Brisbane. He almost immediately saw the country as the right place to start a new experiment. Upon his return to Belgium in September 1852, he wrote a short report, $A u$ Texas, which was welcomed by enthusiastic followers to such an extent that most of them would eventually ignore his warnings concerning the obstacles that stood in the path toward "realization" (Considerant 1854).

By the end of 1853, a "Provisional Convention" was drafted to delimit the scope of the project. Not long after that, a Colonization Society was set up to collect funds and establish lists of prospective settlers. In September 1854, Considerant's longtime friend Félix Cantagrel sailed to America to buy land in southern Texas on behalf of the Society and set up the base of the future colony. The original idea was to wait one more year, during which a group of 150 American pioneers would clear the land, plant crops, and erect rudimentary buildings to shelter the European settlers who would then begin to arrive in small groups.

But it soon became obvious that these plans had gone awry. When Considerant arrived in New York on February 4, 1855, he had to face a series of problems which literally made him sick. Cantagrel had been compelled to seek an alternative site much further north of the area initially chosen - and at a much higher price - because the latter had in the meantime been closed to colonization; the support, including financial support, promised by the American Fourierists had failed to materialize; and the hostility of many Texans toward a project suspected to favor abolitionism made a special grant of free public land by the State legislature quite unlikely. To make things even worse, groups of enthusiastic settlers unable to wait any longer - including physically fragile infants and older people - were already on their way, without knowing as much as the exact location of the future colony, and unaware that there was nothing there to welcome them. After walking for days through the prairie under a scorching sun, they arrived in Reunion exhausted and sick, only to realize that almost everything had still to be done. For a few weeks morale remained high in spite of the fact that the settlers had to work long hours in the fields, were underfed (all the food had to be bought outside the colony at a prohibitive price) and housed in primitive accommodation. The community even experienced a few moments of pleasure and harmony. But the summer of 1855 proved exceptionally torrid and the colony, which numbered 130 members by mid-July, was forced to make do with a shortage of water, not to mention the frightening presence of venomous snakes. Drought ruined many of the crops and, in the fall, an invasion of caterpillars and crickets destroyed all that had been replanted.

In a short time, the already chaotic organization of the colony worsened because of internecine quarrels and divisions. So much so that in the fall, Considerant briefly considered sending $90 \%$ of the settlers back to Europe to restart the colony from scratch. The ensuing financial losses would have been accepted since he expected the land to increase in value spectacularly once Dallas was connected by rail. But the political cost would have been too 
high: one more blatant failure after several others would have definitely ruined the credibility of the Fourierist project. Unable to make this decision, Considerant retreated to his hammock, leaving Cantagrel and Savardan to handle the situation as best they could.

Then a thoroughly disenchanted Considerant left abruptly for Austin in October 1855 to seek in vain the support of the state legislature, and from there to San Antonio, to explore unsettled areas where he might launch an alternative experiment. When he returned to Reunion on March 24, 1856, the colonists were already vaguely aware of his new plans, and the situation was volatile and the community on the brink of disaster.

Yet the settlers had not been inactive during his absence. New buildings had been erected during the winter, including a general store, the cattle herd had grown substantially, the ploughing and planting were well under way, and, thanks to a group of hunters, food was now more varied and palatable. But in early May, cold weather returned unexpectedly. The rivers froze and the prolonged frost destroyed the prospective hay crop and vegetable gardens. Little of what was replanted hastily in the following weeks survived another hot summer.

In the meantime, the number of settlers had increased to over 200. Many disappointed colonists had already left Reunion, but their departure had been more than compensated by new arrivals. Many of the newcomers had traveled on their own initiative, without the prior agreement of the board of directors of the Colonization Society in Paris, who ignored what the situation was really like in Texas. In Reunion, even Considerant's closest friends and allies no longer trusted him.

By the beginning of July, the situation had become critical. The work groups were completely disorganized. Acrimonious and discouraged, the majority of settlers were ready to return to Europe. Before doing so they demanded financial compensation, which was impossible since the financial resources of the colony had been exhausted. Alerted at long last, the Paris directors reacted by sending Allyre Bureau to Texas. Unfortunately, by then it was too late.

After having met Considerant in San Antonio, Bureau reached Reunion in mid-January 1857. His mission was to dissolve the settlement gradually. The situation was so hopeless that Bureau suffered a nervous breakdown. The only option left was to brutally liquidate the colony a few weeks later after 21 months of existence. The last settlers divided the land, cattle and tools among themselves by way of compensation. By 1860, half of the colonists had returned to France; the others were living in the area around Dallas. A single family had decided to remain on the original site.

Thus the Fourierist attempt in Reunion unquestionably ended as a failure. Yet, the dissolution of the colony did not mean the end of the story. Much is still to be said about the event and its legacy, as a brief reexamination of the history of Reunion from two different angles will show. 
Regarding the project itself, as the first large scale attempt to put Fourier's theories into practice, it is necessary to examine how it was conceived and organized and what its objectives were, as well as what this experiment represented in the history of the Fourierist movement (and more generally in the history of French socialism). It will be necessary to examine the American context to see to what extent the lessons of past failures were drawn on, if at all. The question being in the final analysis: was this failure actually the swan song of a romantic conception of socialism, which opened the way to develop a more pragmatic and realistic approach?

As for those who took part in this experiment - those men and women were who had been ready and willing to abandon their country and all they possessed in order to found a harmonious society in the middle of nowhere - one needs to examine who they were, what their expectations were and how they reacted to the failure of this attempt, both individually and collectively.

Evidently, many questions remain to be explored.

What were the main causes of the failed attempt, and what were the main obstacles standing between theory and practice ${ }^{3}$ Firstly, it is necessary to keep in mind that the decision to establish a new colony was a positive choice made in a negative context. As early as 184647 , Considerant had convinced himself that no attempt to create a phalanstery could be viable in the context of political reaction. He had welcomed the February Revolution and the proclamation of the Republic in 1848 in France and played a very active role in the debate about the "right to work". But the June Insurrection and the failure of the Left in the Spring of 1849, his flight into exile to avoid imprisonment, and eventually the coup engineered by Louis-Napoléon Bonaparte, destroyed his hopes. At that point, the main Fourierist leaders began to elaborate their project for a colony. Initially, it was supposed to be set up in Europe; but after the demise of the "Spring of the Peoples" the reaction everywhere in Europe (except, to a certain extent, in Switzerland) was triumphant. Then, during his tour of America with Brisbane, Considerant was subjugated by the Texan landscapes, so much so that his vision of an ideal society became his version of the American Dream. ${ }^{4}$ A greater lucidity about the local conditions would have alerted him to the fact that his so called "favorable" conditions posed many obstacles.

If the Far West offered enough wide open space for anyone to find a place, the gigantism of the USA was such that the settlers found themselves lost in the wilderness, $8000 \mathrm{~km}$ away

\footnotetext{
3 Some of the obstacles faced by the French settlers have been reviewed in detail by Bruno Verlet in his unpublished paper (Verlet 1989).

${ }^{4}$ On Considerant's discovery of Texas and the story of Reunion, see: Beecher 2001, part 4, and Cabiers Charles Fourier, $n^{\circ} 4$ (1994), special "Reunion" issue. See also: Hammond, Hammond 1858; Wolski 1964, 41-68, 137-154; Santerre 1955; Santerre 1936.
} 
from France, with unreliable lines of communication: when a letter was sent to Paris, it took about two months to receive a reply and three months for an exchange. The much vaunted cultural diversity proved to be an illusion. Nativism, still a fledgling political movement in 1853 when Considerant explored Texas, had become quite powerful two years later, fueled by the development of mass-immigration and the economic recession of 1853-54. Foreigners were no longer unanimously welcome in Texas. Despite the absence of a feudal past, the South, including Texas, was dominated by a slave-owning aristocracy enriched by the cultivation of cotton. The mounting inter-sectional tensions about the future of slavery led to the public exposure of Fourierists as "red" Republicans and abolitionists, despite Considerant's protests that he had no intention to interfere with the Peculiar Institution. But the highly heralded presence among the colonists of the well-known American abolitionist John Allen was enough to legitimize the slaveholders' suspicions concerning the true aim pursued in Reunion. As for the economic prosperity of the USA, as described in detail by Considerant in $A u$ Texas, it was far from general. Many local disparities existed, and the recent economic downturn had taken its toll. Last but not least, the once relatively powerful American Fourierist movement had lost its momentum, and little help could be expected from its members. ${ }^{5}$ All these factors contributed significantly to the final failure.

One must also consider the fact that the promoters of each utopian project, convinced of the expression of their own truth, considered it a waste of time to try and learn from the mistakes made by others. In this respect, it is amazing to see that the European Fourierist settlers repeated most of the same errors that had caused the American phalanxes to fail in the preceding decade: ill-chosen location (mediocre fertility, difficult climatic conditions...), lack of reliable means of communication, unfavorable social and political environment, not to mention the untimely arrival of a great number of settlers unprepared for frontier life or for the undertaking of pioneering tasks. At no time were there more than ten experienced farmers on the site, while there were plenty of unproductive former employees and intellectuals, as well as infants and older people unable to work. In any case, the lack of practical sense on the part of the project's initiators was blatant. Having initially spent half of their $\$ 200000$ capital to buy thousands of acres of land (57000 altogether) for which they had no use, they found themselves short of money from the start. Even if they had managed to cultivate corn and vegetables on a large scale as planned, they would have found no commercial outlet for their production. In 1855, Dallas, the only town in the vicinity, had fewer than 400 inhabitants (it was not pronounced a municipality until 1856).

\footnotetext{
5 To understand the complex reasons that caused the rise and fall of the Americain Fourierist movement, see Guarneri 1991.
} 
With regards to Reunion specifically, one must also note the ambiguity of Considerant's initial project. His intention was to create a "champ d'asile" open to all sorts of social experiments, where the followers of various reform groups would be given a chance to put their theories into practice. Only rudimentary facilities (a dining hall, a kitchen, a library, an infirmary, a school, a general store, etc.) would be established to serve the community as a whole. But the Fourierists who responded to his call saw things differently. From the start, their intention was clearly to build a phalanstery, and for them it was out of the question to compete, even pacifically, with other social reformers. This led to conflicts, disagreements, and divisions among the colonists.

There was also a lack of coherence in Considerant's project which tended to favor speculative profits from the selling of improved land, as any ordinary colonization society or professional developer might have done, over profits derived from the productive work of the settlers. This was doubly ironic given that, on the frontier, human capital was by far the most valuable commodity as there was always a permanent shortage of manpower, and the Fourierists claimed to know better than anyone how to combine human passions to bring out the best in their followers as workers.

All this raises the issue of leadership. Considerant may indeed be accused of two contradictory sins: to have been too efficient a propagandist and too poor a leader in action. His description of Texas as the Promised Land and his painting of a harmonious future society had given birth to unreasonable expectations among the Fourierist rank and file. But once confronted with reality and the mass arrival of prospective settlers that his eloquence had successfully convinced to abandon their former lives, he proved unable to make the right decisions and to act as a genuine leader. He finally fled, abandoning the colony to its sad fate and an inevitable demise while pretending to work on new projects.

The final irony might be that, whereas Fourier himself had anticipated the potentially destructive nature of human passions, his heirs demonstrated haphazardly that a few serial combinations or practical tricks would not be sufficient to eliminate the problem.

Yet, whereas the conclusions regarding the social experiment turn out to be largely negative, the situation appears more contrasted if we look at the participants both individually and collectively.

Collectively speaking, the demise of the colony was certainly deeply resented by the Fourierists. Yet, it did not signal the end of Fourierism as an organized movement. It would be more appropriate to say that it closed its romantic phase. It was indeed the last attempt to lay the foundations of an ideal society resembling more or less what Fourier and his disciples had imagined prior to the 1848 Revolution. As soon as the early 1860s, Fourierism was again a well identified current of thought on the French political and social scene: Fourierist journals and reviews continued to appear until 1922, and new forms of personal involvement were 
explored by the Fourierists, especially in the cooperative movement (foundation of the Crédit au Travail together with the former Icarian Béluze, important participation in the International Workingmen's Association during its early mutualist phase, not to mention the well-known social experiment in the Familistère in Guise) (Cordillot 1992, 53-67; Desmars 2010; Lallement 2009). One may also trace Fourierist influences in the political Left, with a continuity leading from Considerant to Benoît Malon and later Jean Jaurès ${ }^{6}$.

But the consideration of the individual trajectory of the participants is even more interesting ${ }^{7}$. Reviewing their life stories may help us to understand the importance of this episode in their lives and how they reacted individually to the demise of the colony.

Slightly more than 300 settlers took an active part in the Texan experiment. By 1860, about half of them were back in Europe. The others had decided to stay in the USA.

Concerning those who returned to France, it is worth noting that there was no spectacular case of public denunciation or abjuration, nor were there law suits as had been the case following the initial failure of the Cabetists in Texas. Most of the anonymous rank and file Fourierists returned quietly to anonymity to try and start a new life (or resume their former one). But a few gained some prominency, such as Alexis Bessard, who had been appointed administrator of what was left of Reunion after Bureau's untimely death in 1859. In 1861, Bessard was asked to sell off as much of the remaining estate as he could on behalf of the shareholders of the Colonization Society and to repatriate the money to France. Immediately after the fall of the Empire and the war with Prussia, he was elected republican mayor and county representative of Tournus (Saône-et-Loire). Reelected in 1888, he was succeded by his son (also a former colony member) at the City Hall from 1896 to 1908. Auguste Savardan, who had been one of Considerant's staunchest opponents, returned to France bitterly disillusioned and wrote a book in which he was highly critical of his former leader (Un Naufrage an Texas 1858). Yet he remained a convinced Fourierist, taking part in the reorganization of the movement and writing articles for its publications. Elected mayor of his small town, La Chapelle-Gaugain, he delivered educational conferences for the local peasants and farmers (Cosnier, Desmars 2011). Félix Cantagrel, who for the rest of his life remained at daggers drawn with Considerant, settled in Switzerland before returning to France after the 1859 amnesty. He worked as a journalist and was actively engaged in both the cooperative movement and the Republican ranks after the demise of the Empire. Openly sympathizing with the Paris Commune, after its fall he became one of the major artisans of the reorganization of the Parisian trade unions and supervised the election of the trades' delegates to the Universal Exhibition of 1873 in Vienna. Alderman of Paris in 1875, he was also elected to the National

\footnotetext{
${ }^{6}$ See for example: Vincent 1992.

${ }^{7}$ Biographical information concerning most of the participants can be found in: Cordillot et al. 2002.
} 
Assembly. Together with the Far Left, he battled in favor of amnesty for the Communards and for the definitive proclamation of the Third Republic ${ }^{8}$. As for the Swiss Karl Bürkli, he took a few months after the demise of Reunion to tour Central America before returning to Switzerland in 1861. He was one of the founders of the First International in his country, and remained actively engaged in the socialist movement until his death. In 1893, at the Zurich congress of the Second International, he took the stand to deliver a speech honoring Fourier as a precursor of modern socialism 9 .

For all these people - though little is known about most of those who went back to Europe - it appears clear that the failure of Reunion did not mean an end to their social and political commitment even though it subsequently took a different form.

Even more conclusive is the story of those who chose to stay in the USA ${ }^{10}$. The farmer François Santerre was the last colonist to arrive in Reunion with his family. Contrary to most of the others, he was fully aware of the hardships awaiting him. After the demise of the colony, he stayed in Reunion on a 200 acre farm which operated as an autonomous family phalanx. Within a few years, he managed to save 4000 gold dollars (later lost in hazardous speculations). Still attentive to the evolution of the political situation in France - where he returned six times - he also remained a committed socialist, joined the Dallas branch of the International Working Men's Association (First International), and wrote in 1874 in one of its publications that he was still "in favor of integral association". As an ironic post-scriptum to the debacle, François Santerre and his six children managed to establish a mini phalanstery where the grandiose projects of Considerant had failed to materialize.

There are several other examples. Carpenter Charles Capy settled in Dallas. Charter member of section 46 of the First International, he was also elected alderman in the First ward; by 1904 he was still a subscriber to the Parisian Fourierist journal La Rénovation. A reckless fighter during the Civil War in the Confederate Army, Émile Rémond married one of François Santerre's daughters, constructed the first brickyard in Dallas and a cement plant; also a member of the IWPA, he became a collector of Indian antiquities and fossils. Athanase Chrétien, a harness maker, settled in Dallas as well; a staunch member of the IWPA, in 1875 he sent a long declaration extolling Fourierist theories to the socialist newspaper Bulletin de l'Union républicaine which was published in New York. His son George, born in Reunion, later gave his father's books to the Dallas Historical Society. Christophe Désiré Frichot, a former jeweler, had previously taken part in the failed attempt led by Dr Benoit Mure to establish a phalanstery in Brazil (Vidal 2014); after the demise of Reunion he tried to operate a jewelry

\footnotetext{
8 http:/ / maitron-en-ligne.univ-paris1.fr/spip.php?article159705

${ }^{9}$ http:/ / maitron-en-ligne.univ-paris1.fr/spip.php?article159407

10 See: Cordillot et al. 2002.
} 
store in Dallas but was compelled to close it. He then decided to establish himself as a brickmaker with his brother. Also a member of the IWPMA, he gave financial aid to the communard refugees and the socialist press. His family eventually became rich when Dallas expanded, causing the tracts of land he had secured after the dissolution of the colony to become the object of wild speculation.

The Swiss Benjamin Lang, who had been the youngest member of Reunion, married the daughter of a Belgian Fourierist. Due to his courageous pro-union stance, he was appointed mayor of Dallas in 1868 by the military governor of Texas (in the meantime he had Americanized his name to Ben Long). He resigned in 1870 and went back to his mother country to recruit immigrants whose arrival greatly contributed to the economic development of Dallas (Verlet 1988). He was re-elected mayor from 1872 to 1874, appointed as US commissioner, and later elected sheriff. He was killed not long after in a street shooting during a cowboy brawl. Louis Louis, a former blacksmith who had been forced to flee in exile after December 2, 1851, did not remain in Dallas long after the dissolution of Reunion. He settled instead in New Orleans where he remained very politically active. On April 7, 1868 he organized the celebration of Fourier's $96^{\text {th }}$ anniversary. He cofounded section 15 of the International, voted a message of support to the Paris Communards, and died soon after in November 1871 (Cordillot 1993).

The above examples - along with others that cannot be mentioned due to space limitations - suggest a number of things. First, it appears that the entrepreneurial inclinations of these men were stimulated rather than suppressed by the failure of Reunion. For most of them, the Texas debacle was simply an incident in their lives. So much so that, at least for those who stayed in the USA, it would be erroneous to call it an absolute failure. Even though they did not create the ideal society they had dreamed of, they largely contributed to the emergence of the town of Dallas (and its future prominence as a major Texan city). They contributed to its development by opening businesses such as a butcher shop and a grocery store; by giving Dallas one mayor, several aldermen and other public officials; and through their strong involvement in various local societies and masonic fraternities. Equally decisive was their contribution to the cultural life of the nascent city: Allyre Bureau brought with him one of the first pianos, Charles Capy organized a choral society, Julien Reverchon studied the local flora, François Santerre bequeathed his library to the local University, and Émile Rémond his collections of antiquities to the local museum.

Whereas most of the Fourierists colonists had arrived in Texas as destitute European immigrants, they had become prosperous American entrepreneurs by the time they died. Nevertheless, most of them continued to believe in Fourierism, or at least in some form of illdefined socialist messianism (Cordillot 1989). After their dreams of phalanx had vanished, many joined the ranks of the organization that was to bear the flag of world socialism during 
the following years, The International Working Men's Association. This was true in the USA where former Reunion colonists founded sections 15 (New Orleans) and 46 (Dallas), contributed financially to the survival of French-language socialist newspapers such as Le Socialiste and the Bulletin de l'Union Républicaine de Langue Française (New York City), La Commune (New Orleans), L'Étoile des Paurres (Neuchatel, Kansas), and their ideological influence could be seen at work in other sections (New York, Philadelphia). The same was also true in Europe: besides Bürkli in Switzerland, Considerant himself joined the International after his return to France in 1869, and Godin, who had lost practically all the money he had personally invested in the Texan colony (about one third of the initial capital of the Colonization Society), took enough of an interest in the First International to attend one of its general congresses while pursuing his industrial venture of the Familistère in Guise.

More generally, if one broadens the scope to include other utopian schools of thought, there are a number of points of note:

- that former Icarians and followers of Cabet were, in 1869, the real initiators of the Union Républicaine de Langue Française in Saint Louis (which gave birth a few months later to the first French language sections of the IWMA in the USA);

- that among the projects debated by American members of the IWMA, several concerned agricultural colonies including the neo-Fourierist project drafted by section 15 in New Orleans;

- that there were several attempts to create such colonies (including one in Louisiana which was officially sponsored by section 15 , one in Venezuela in which several former Communards were involved, and another in Honduras headed by Charles Caron, former secretary of section 15);

- that a group of Communard exiles lacking any other political perspective decided in 1876 to settle in Iowa among the Icarians;

- and last but not least, that in the main American cities, for all the French exiles who called themselves revolutionary communists (most of them Blanquist sympathizers), taking part in the edification of an ideal society in Icaria - on whose internal affairs they kept a close watch and frequently took positions - was a perfectly legitimate form of action.

All in all, analysis of individual trajectories of the French-speaking radicals in the USA during the 1848-1880 period tends to demonstrate that, for most of those involved, fighting on the barricades, creating cooperative associations, tilling the land in a far western agricultural colony, being trade-union activists, and joining the nascent party of international socialism were seen as different facets of the same struggle: the struggle against the oppression of capital and for 
a more equalitarian society. Moreover, they obviously posited no qualitative hierarchy between these various forms of militancy.

The Icarian tailor Arsène Sauva is a case in point to illustrate this ${ }^{11}$. He arrived in the USA in 1860 together with his future wife to join the Icarian settlement in Cheltenham (Missouri). When the Civil War broke out in 1861, many of its members enlisted in the Union army, leaving Sauva to serve as its interim president until the final closure of the community in 1864. He then fought in the Union Army until the end of the war. Demobilized, he returned to France where he was actively involved in the cooperative movement. Briefly sent to prison for his participation in a strike of the tailoring trades, he subsequently joined the IWMA, organized a tailors' cooperative during the First Siege of Paris, and fought in the communards' ranks as a sergeant. He managed to avoid being arrested or shot, left Paris and returned to New York. There he worked as an administrator of Le Socialiste and cooperated with the Blanquists, which resulted in him being elected to represent three French language sections of the IWMA at The Hague Congress in September 1872. When back in the USA, he was elected secretary of the Society of the Commune Refugees and also corresponding secretary of the New French Language branch of the IWMA born from the fusion of several groups of activists. Present at the Tompkins Square riots of January 1874, he was one of the officers elected to command the armed militias that the French militants tried to set up to fight back the police forces. Then, in April 1876, Sauva decided to leave New York to join the Icarian colony still active in Corning (Iowa). He rapidly emerged as a leader able to preserve a semblance of unity among the divided and aging community. Because he had kept plenty of contacts in socialist circles, he convinced a handful of former communards to come and reinforce the colony. When the community finally split, Sauva remained faithful to the Old Icaria (though not without conceding that some of its critics were not entirely wrong). He wrote several leaflets and secured the support of a sizable group of French revolutionary communists in New York City. In Iowa, he and his wife held various responsibilities until they decided to return to New York City in 1884. There Sauva contributed to the emergence of the French language anarchist movement linked to the IWPA - soon to become famous for its involvement in the Haymarket affair in Chicago (1886). By the end of the 1880s, Sauva finally returned to France, settled in Paris to open a tailor shop, and died in 1896.

The least that can be said is that such a personal itinerary illustrates a permanent will to find the best way to work for the regeneration of society, with no form of activism being a priori deemed inacceptable.

If one accepts the idea that history is the product of the collective action of men and women, then the above should lead to a reconsideration of the relevance of the distinction

11 http://maitron-en-ligne.univ-paris1.fr/spip.php?article159448 
(almost exclusively theoretical) that has too often been made between so-called "utopian" (or romantic) socialism and so-called "scientific" (or realistic) socialism. Reconsidering the Reunion experiment and the life stories of its participants, and looking beyond the simple acceptance that it was a complete failure may also provide a better idea of the gap between theory and practice, and of the complex problems faced by those who tried, or are still trying today, to build a more just society. 


\section{References}

Cabiers Charles Fourier, n 4 (1994), special "Reunion" issue.

Un Naufrage au Texas. Observations et impressions recueillies pendant deux ans et demi au Texas et à travers les États-Unis d'Amérique. 1858. Par le Dr Savardan, auteur d'Asile rural d'Enfants trouvés. Paris: Garnier frères.

Beecher, Jonathan. 2001. Victor Considerant and the Rise and Fall of French Romantic Socialism. University of California Press.

Considerant, Victor. 1854. Au Texas. Paris: Librairie phalanstérienne.

Cordillot, Michel. 1989. Les derniers fouriéristes français aux États-Unis. Notes et documents". LUVAH, special issue "Charles Fourier": 103-116.

Cordillot. Michel. 1992. Le Fouriérisme dans la section parisienne de la Première Internationale, 1865-1866. Cahiers Charles Fourier, n ${ }^{\circ}$ 3: 53-67.

Cordillot. Michel. 1993. Le socialisme francophone néo-fouriériste après Réunion: Charles Caron et la section 15 de l'Internationale à La Nouvelle-Orléans. Cabiers Charles Fourier $\mathrm{n}^{\circ}$ 4: 129-142.

Cordillot. Michel et al. 2002. La Sociale en Amérique. Dictionnaire biographique du movement social francophone aux États-Unis, 1848-1922. Paris: Les Éditions de l'Atelier.

Cordillot, Michel. 2013. Utopistes et exilés du Nouveau Monde. Des Français aux États-Unis de 1848 à la Commune. Paris: Vendémiaire.

Cosnier, Colette and Bernard Desmars. 2011. Savardan Auguste (parfois prénommé Augustin). Dictionnaire biographique du fouriérisme, notice posted in July 2011. http://www.charlesfourier.fr/spip.php?article909 (access: 27th August 2017).

Desmars, Bernard. 2010. Militants de l'utopie? Les fouriéristes dans la seconde moitié du XIXe siècle. Dijon: Les Presses du réél.

Fourn, François. 2014. Étienne Cabet ou le temps de l'utopie. Paris: Vendémaire.

Guarneri, Carl. 1991. The Utopian Alternative. Fourierism in Nineteenth Century America. Ithaca: Cornell University Press.

Hammond, William J. and Margaret F. Hammond. 1858. La Reunion, A French Settlement in Texas. Dallas: Royal Publishing Company.

Lallement, Michel. 2009. Le Travail de l'utopie. Godin et le Familistère de Guise. Paris: Les Belles Lettres.

Pratt, James. 2018 (forthcoming). Sabotaged. Dreams of Utopia in Texas. University of Nebraska Press.

Prudhommeaux, Joseph. 1907. Icarie et son fondateur Étienne Cabet. Paris: Cornély.

Santerre, George H.1955. White Cliffs of Dallas. The Story of La Reunion, the Old French Colony. Dallas: The Book Craft.

Santerre, Elö̈se. 1936. Reunion, a Translation of Dr Savardan's 'Un naufrage au Texas', with an introduction to Reunion and a Biographical Dictionary of the Settlers. M.A. Thesis. Dallas: Southern Methodist University.

Verlet, Bruno. 1989. Quand des Suisses construisaient Dallas. Mudée Neuchahâtelois, 4: 209-218

Verlet, Bruno. 1989. The Phalanx of No Return. The La Reunion Colony, Dallas: A Case of French Smugness on the Frontier. (Unpublished paper).

Vidal, Laurent. 2014. Ils ont rêvé d'un autre monde Paris: Flammarion. 
Vincent, K. Steven. 1992. Between Marxism and Anarchism. Benoit Malon and French Reformist Socialism. Berkeley: University of California Press.

Wolski, Kalikst. 1964. New Light on La Reunion. From the Pages of "Do Ameryki i w Ameryce". Trans. and ed. Marion Moore Coleman. Arizona and the West. 
Michel Cordillot - Professor emeritus, University of Paris 8. French historian and translator, specialized in the history of social movements in the $19^{\text {th }}$ century and the French émigré communities in the United States in the $19^{\text {th }}$ and early $20^{\text {th }}$ century. One of the founders of the journal Cabiers Charles Fourier, an author of a number of articles and books (eg. Eugène Varlin, internationaliste et communard; (ed.) La Sociale en Amérique. Dictionnaire biographique du mouvement social francophone aux États-Unis, 1848-1922; Révolutionnaires du Nouveau monde: une brève histoire du mouvement socialiste francophone aux États-Unis, 1885-1922; Utopistes et exilés du nouveau monde aux États-Unis de 1848 à la Commune).

\section{DANE ADRESOWE:}

Université Paris 8

Département d'Études des Pays Anglophones

2, rue de la Liberté, 93526 Saint-Denis

France

EMAIL: michel.cordillot@wanadoo.fr

CytowANIE: Cordillot, Michel. 2018. „Rethinking the failure of the French Fourierist colony in Dallas" Praktyka Teoretyczna 3(29): 118-133.

DOI: $10.14746 /$ prt.2018.3.6

AUTOR: Michel Cordillot

TYTuŁ: Przemyśleć na nowo upadek francuskiej kolonii fourierowskiej w Dallas

ABSTRAKT: Panuje ogólna zgoda co do tego, że próba utworzenia francuskiej kolonii fourierowskiej w Dallas w przededniu wojny domowej zakończyła się całkowitym niepowodzeniem. Ale czy rzeczywiście tak było? Przemyślenie dziedzictwa tej kolonii ukaże, że kwestia ta jest dużo bardziej złożona i daleko idąca, niż dotąd sądzono.

SŁOWA KLUCZOWE: dziewiętnasty wiek, falanster, Fourieryzm, La Réunion, Texas, Victor Considerant 